\title{
Edmund Kizik
}

\section{Goldwasser i jopenbier. Produkcja wódki i piwa w Gdańsku w długim XIX wieku (do 1914 roku)}

\begin{abstract}
Abstrakt: Produkty gdańskich browarników i destylatorów, szczególnie ciężkie piwo jęczmienne (jopenbier) oraz korzenne likiery, cieszyły się w XVII-XVIII w. wielką sławą w Polsce, w całej Europie Środkowej i Wschodniej. Smak oraz wygląd gdańskiej wódki (Goldwasser) sławili poeci niemieccy, a jej legenda trafiła nawet na strony polskiego eposu narodowego Pan Tadeusz (z 1834 r.). Autor artykułu przedstawił sytuację gdańskiego rzemiosła gorzelniczego oraz browarniczego od schyłku XVIII w. do wybuchu pierwszej wojny światowej. Na podstawie statystyk handlowych ukazano zmieniającą się strukturę wytwórców, wielkość, ceny produkcji oraz eksport, a także reakcję na zmieniające się gusty konsumentów w epoce przemysłowej.

Abstract: The products of Gdansk brewers and distillers, especially the heavy barley beer (jopenbier) and spicy liqueurs, were famous in Poland and throughout Central and Eastern Europe in the 17th c. and 18th c. The taste and appearance of Gdansk vodka (Goldwasser) was praised by German poets and its legend even found its way into the pages of the Polish national epic poem "Pan Tadeusz" (1834). The author of this article presented the situation of the Gdansk distilling and brewing craft from the end of the 18th century until the outbreak of the First World War. Based on trade statistics, he presents the changing structure of manufacturers, the volume and prices of production, exports and the reaction to changing consumer tastes in the industrial era.
\end{abstract}

Słowa kluczowe: goldwasser, jopenbier, alkohol, browarnictwo, gorzelnictwo, Gdańsk, XIX w. Key words: goldwater, dantzic spruce, brewing, distillation, Gdańsk, 19th c.

„Sędzia otworzył puzderko zamczyste, W którym rzędami flaszek białe sterczą głowy; Wybiera z nich największy kufel kryształowy, [...] Wódka to gdańska, napój miły dla Polaka; Niech żyje! krzyknął Sędzia, w górę wznosząc flaszę, Miasto Gdańsk, niegdyś nasze, będzie znowu nasze!"1.

Któż nie zna tego cytatu z 1834 r., którego proroczy toast przypominał pokoleniom rodaków związki Gdańska z Polską? Gdańskie wódki, równie często opiewane przez niemieckich poetów² ${ }^{2}$ cieszyły się wielką popularnością w wieku XVIII i na początku XIX³ wśród polskiej

1 Mickiewicz A. 1834, s. 183.

2 Wedekind Ch.F. 1746; Lessing G.E. 1767, s. 6: Behüte! vertitabler Danziger! ächter, doppelter Lachs; Kleist von H. 1811, s. 36: ein Gläßchen Danziger etwa.

3 Podstawowym opracowaniem nowożytnego gorzelnictwa i piwowarstwa pozostają syntezy: Klonder A 1983; Klonder A. 1989; por. też: Blänckenburg von Ch. 2000, s. 125-145 (zarys browarnictwa w Gdańsku); dla gorzelnictwa zob.: Trzoska J. 1984, s. 145-187. Współczesne badania nad kulturą konsumpcji w nowożytnej Polsce, zob.: Kizik E. 2019, s. 12-52. 
szlachty $^{4}$, trafiały też na dwory europejskich monarchów ${ }^{5}$. Wielką sławę miało także warzone od średniowiecza w Gdańsku piwo, „[...] które oni [gdańszczanie - E.K.] Jopenbir a pospólstwo Dupelbier zowią [...] a to bywa ciemnorumiane, mocne y pijane, posilające a iako syrop gęste" (1613 r. $)^{6}$. Jopenbier ${ }^{7}$, czyli ciężkie, słodkawe piwo jęczmienne porównywane z brunszwickim mumme (schiffsmumme, angielskim mum), należało do ciemnych piw warzonych i chętnie spożywanych w miastach hanzeatyckich i Niderlandach ${ }^{8}$. Jednak największym odbiorcą trunku była Anglia ${ }^{9}$, gdzie znano je pod określeniami double brown stout, sprouts, prussian spruce lub w nawiązaniu do pochodzenia — dantzig spruce albo dantzic black beer ${ }^{10}$. Jopenbier zwykle nie spożywano w pierwotnej formie, lecz traktowano też jako dodatek uszlachetniający smak portera lub lekkich piw, o krótkiej przydatności do spożycia ${ }^{11}$.

Legendy o gdańskiej wódce i piwie miały się dobrze, o czym świadczyły zarówno opinie Polaków odwiedzających miasto w XIX w. ${ }^{12}$, jak i ich naiwne naśladownictwa opisywane w książkach kucharskich z epoki ${ }^{13}$. W Gdańsku w drugiej połowie XVIII w. działało co najmniej 20 mistrzów piwowarskich i 14 gorzelniczych ${ }^{14}$; maksymalna liczba wytwórni była regulowana wilkierzem z 1761 r. ${ }^{15}$ Ograniczenie konkurencji osłabiło potencjał produkcyjny, co skutkowało trudnościami np. przy realizacji wielkiej umowy na dostawę wódki do Rosji w latach 1767-1768 ${ }^{16}$. Wiele konkurencyjnych gorzelni działało na przedmieściach Gdańska (Stare Szkoty, Chełm), które nie podlegały jurysdykcji miasta, lecz znajdowały nabywców wśród mieszczan. Po pierwszym rozbiorze Polski Prusacy połączyli te osady w konkurencyjne dla Gdańska miasto Chełm (Kombinierte Städt Stolzenberg) ${ }^{17}$. W spisie mennonitów z podgdańskich osad z 1776 r. odnotowano działalność 17 tamtejszych wytwórców, członków tego wyznania, łączących handel korzenny z gorzelnictwem i destylowaniem wódek gatunkowych („GewürtzKrämer-Brandtwein-Disstileteur”, „Brandwein-Brenner”) ${ }^{18}$. W mieście w 1794 r. działało 18 gorzelni, w 1805 - 20, w latach 1804-1805 ich liczba spadła do 16. Najwięcej, bo 7 go-

${ }^{4}$ Romanow A. 1983, s. 183: „4 flasz[e] wódki ze złotem” w cenie 1 fl. i 5 gr., zakupiono w Gdańsku dla Pawła Benoego w 1750 r.; Rostworowski S.M. 1933-1934, s. 361: „wódki alkiermesowey ze złotym, sztow jeden”; Kitowicz J. 1985, s. 241-242: „wódka gdańska”, „Krambambula”. S. 165 .

5 Caryca Elżbieta w 1767 r. miała nabyć likiery z wytwórni „Pod Łososiem” za 5125 fl., Trzoska J. 1984,

${ }^{6}$ Piwo „ciemnorumiane, mocne i pijane, posilające, a jako syrop gęste”, Syrennius S. 1613, s. 946; por:: Klonder A. 1983, s. 104, tam również (s. 105-107, tab. 3) normy zużycia słodu na beczkę piwa jęczmiennego.

7 Współcześnie upowszechniło się również polskie określenie ,piwo jopejskie”, zob. hasło „Piwo”, Gedanopedia. 2021. W niniejszym artykule posługuję się konsekwentnie określeniem źródłowym.

${ }^{8}$ Charakterystyka piwa w: Klonder A. 1983, s. 98; Klonder A. 1989, s. 38.

9 Biernat Cz. 1993, s. 48.

10 Zob.: Cornell M. 2016, s. 2-14 (autor zebrał przykłady źródłowe z XVI-XIX w.); zob. ofertę „Dantzic Spruce", Dover Telegraph. 1834, 18 I 1834 r. i 15 III 1834 r.

11 Spostrzeżenie Andrzeja Klondera poczynione dla XVI-XVII w. (Klonder A. 1983, s. 108) znajduje potwierdzenie również $\mathrm{w}$ praktyce $\mathrm{w}$ XIX $\mathrm{w}$.

12 Stanisław Tarnowski pisał w 1881 r.: ,jest pod Łososiem skład gdańskich wódek, główna na cały świat fabryka sławnego Goldwassera i jego stolica”, Tarnowski S. 1882, s. 54, również s. 32.

13 „Wódka złota, czyli Goldwasser: [...] wlej garniec spirytusu, wymieszaj, przedystyluj [...] potem zamocz koniec pręcika w wodzie, okręć go potartem złotem papierowym, czyli malarskiem, włóż do butelki, skłóć z wódką, gdyby pływały drobne skałeczki w wodzie, zakorkuj i zachowaj do użycia”, Dabkiewicz J. 1838, s. 93; zob.: „Sposób robienia wódek gdańskich, doświadczony y rzetelny”, Wiadomość ciekawa. 1769, s. 166-169.

14 Trzoska J. 1984, s. 150, tab. 1, spis gorzelników z 1739 r.

15 Neu-revidirte Willkühr. 1783, s. 26, Erläuterungen und Zusätze.

16 Trzoska J. 1984, s. 172 i tab. 3.

17 Marcinkiewicz A. 2018, s. 226-251. Według Gotthilfa Löschina w podmiejskich osadach Chełmie i Starych Szkotach działało rzekomo aż 160 warsztatów piwowarskich, Löschin G. 1837, s. 19.

${ }^{18}$ Ludwig K.-H. 1961, s. 161-165; Kizik E. 1994, s. 101. 
rzelni, znajdowało się na Dolnym Mieście (14 kotłów), na Starym Mieście - 5 (5 kotłów), zaś na Przedmieściu - 2 (2 kotły), ponadto 2 gorzelnie działały w podmiejskim Nowym Porcie i we Wrzeszczu ${ }^{19}$. Przerabiały one 2764 korców śrutu, wytwarzając 757644 kwart wódki w 1804/1805 r. i 796200 kwart w roku następnym (1 kwarta =1,145 1). Gdańsk po drugim rozbiorze skorzystał na zniesieniu granic celnych i dostępu do rynków zbytu na polskim zapleczu. Niestety brak dostatecznych źródeł do określenia skali sprzedaży wódek i piwa na rynku wewnętrznym ${ }^{20}$, dysponujemy jedynie statystykami sprzedaży drogą morską ${ }^{21}$. Wynika z nich, że aż 96\% piwa wywożonego z Gdańska w latach 1793-1805 trafiało do Anglii. Cena piwa w zależności od użytego słodu kształtowała się w Gdańsku w 1796 r. od 9 fl. przy użyciu 1 korca na beczkę (słabe piwo), do 13 fl. przy użyciu 11 korca na beczkę mocnego piwa. Sztof $\left(1,4\right.$ l) mocnego piwa w wyszynku kosztował 14 fl., zaś 10 fl. płacono za piwo słabe ${ }^{22}$.

Równocześnie do Gdańska sprowadzano w dużych ilościach angielskie piwo, rum i francuskie brandy. Tylko w 1803 r. wwieziono z Anglii aż 10781 beczek, 16362 beczek w 1804 r. oraz 17225 beczek w 1805 r., co znacząco przewyższało cały wywóz piwa ${ }^{23}$. I o ile w ostatnich latach XVIII w. bilans obrotów tymi towarami był jeszcze dodatni, to już od $1800 \mathrm{r}$. import piwa znacząco przeważał nad eksportem. W latach 1803-1804 gorzelnie gdańskie wyprodukowały 757644 kwart wódki i 796200 w roku następnym (beczka = 100 kwart). Duże ilości eksportowane były do Anglii, Hiszpanii i Portugalii i Francji, jednak największym odbiorcą była Rosja.

Okres pomyślnej koniunktury gospodarczej przerwały wojny napoleońskie. W czasie oblężeń Gdańska w latach 1807 i 1812 zburzono przedmieścia wraz z tamtejszymi gorzelniami i browarami. Dodatkowym ciosem dla eksportu stała się blokada handlu z Anglią. Import z Gdańska zastąpiły trunki opatentowane przez angielskich przedsiębiorców, którzy wnet znaleźli sposób produkcji „gdańskiego jopenbier”: [...] a method of making and compounding a certain liquid composition, called Danzic or Dantzic Spruce, or Danzig or Dantzic Black Beer $(1807 \text { r. })^{24}$. Naśladowcom napitku zachwalanego jako środek zapobiegający m.in. reumatyzmowi, przeziębieniu i „wewnętrznej słabości”, grożono surowymi karami ${ }^{25}$.

Po roku 1814 i po ponownym wcieleniu Gdańska do Prus, a tym samym po usunięciu barier celnych oraz ograniczeń antykonkurencyjnych, nastąpiła odbudowa potencjału produkcyjnego. Według księgi adresowej z $1817 \mathrm{r}^{26}$ oraz zestawień statystycznych produkcją piwa zajmowało się 30 warsztatów miejskich i 6 przedmiejskich, 10 warsztatów produkowało spirytus (dodatkowo 8 na przedmieściu) i aż 72 wytwórnie (i 17 na przedmieściu) wytwarzały wódki gatunkowe. Więcej czasu potrzebowano na ponowne zawiązanie kontaktów handlowych. Wywóz piwa w 1819 r. to zaledwie 910 beczek $^{27}$, czyli 40\% eksportu z ostatniego roku przed wybuchem wojny (czyli z 1805 r.) i aż czterokrotnie mniej w porównaniu z rekordowym rokiem 1803. W 1819 r. browarnicy gdańscy zużyli do celów produkcyjnych zaledwie 648 łasztów słodu ( 1 łaszt $=2400 \mathrm{~kg})$, a w najlepszym roku 1804/1805 było to prawie 6 razy więcej 3696 łasztów. W większości warzono piwo jęczmienne w gatunku jopenbier, zużywając

19 Wutstrack Ch.F. 1807, s. 393 (266); Barylewska-Szymańska E., Maciakowska Z. 2016, s. 212-213 oraz szynki s. 224-225.

${ }^{20}$ Dokumentacja gdańskiego magistratu miejskiego z XIX w. zaginęła w $1945 \mathrm{r}$.

21 Biernat Cz. 1962, tab. 37.

22 Gerber [?]. 1797, s. 286.

23 Statystyka przywozu do Gdańska wina, angielskiego piwa, rumu, brandy i winnego octu w latach 1793-1805, Wutstrack Ch.F. 1807, s. 334 (210).

${ }^{24}$ Literary Panorama. 1808, vol. 3, March, szp. 422, List of Patents for Invations.

25 Ten Pounds Reward will be given upon conviction of any person in this kingdom making and vending an imitation of Danzic Spruce, Public Ledger. 1807, 1 X i 27 X.

${ }^{26}$ Adreß-Buch. 1817, s. 124-125 — piwowarzy; s. 128-130 - gorzelnicy. W dalszym ciągu większość gorzelników była wyznania menonickiego.

${ }^{27}$ Uebersicht. 1820, s. 22-23; s. 25-30 - tabela struktury miejscowego rzemiosła. 
w całym powiecie gdańskim w 1816 r. 89284 korców jęczmienia i zaledwie 151 korca pszeni$\mathrm{cy}^{28}$. Dane statystyczne z lat 1827 i 1828 świadczą już o poprawie sytuacji, albowiem eksport wyniósł 2298 i 2764 beczek (po 100 kwart) ${ }^{29}$. Angielskie źródła raportowały o imporcie w $1829 \mathrm{r}$. 24950 baryłek $^{30}$. To sporo i nie dziwi, że w Klubie Pickwicka, sławnej powieści Charlesa Dickensa z lat 1836-1837, zamieszczono wzmiankę o sprzedaży gdańskiego piwa: In the lower windows [...] two or three printed cards, bearing reference to Devonshire cider and Dantzic s pruce [podkr. - E.K.], while a large blackboard, announcing in white letters to an enlightened public, that there were 500,000 barrels of double stout in the cellars of the establishment (rozdział 21) ${ }^{31}$. Gdańskie piwo przebiło się do angielskiej kultury popularnej, chociaż w miejscu powstawania było coraz rzadziej spożywane. Miasto na potrzeby swoich mieszkańców sprowadzało duże ilości piwa jasnego, również typu bawarskiego, co skutkowało nawet powstaniem specjalnej kategorii piwiarni — tzw. Bairische Bierstuben ${ }^{32}$.

$\mathrm{Na}$ tym tle eksport wódek był nieznaczny. Zapewne związane to było z wysoką ceną tych gdańskich trunków. Według liczącego ponad 60 pozycji cennika wyrobów sławnej wytwórni „J. Wed-Ling Wittwe u. Eydam, Dirk Hecker”, powszechniej znanej jako „Pod Łososiem”, w 1805 r. za sztof $(1,4$ l) najlepszych wódek gatunkowych liczono niekiedy nawet ponad $10 \mathrm{fl}$. Na przykład Wein-Goldwasser kosztował 10 fl., Doppel Goldwasser - 5 fl. 24 gr., droga była jałowcowa Krambambuli - 10 fl. oraz Parfait amour — 10 fl., Barbade kosztował 9 fl. 18 gr., zaś Wein-Cordial - 10 fl. 24 gr. ${ }^{33}$ Zwykłe wódki gatunkowe kosztowały po $2 \mathrm{fl} .18$ gr za sztof trunku, a cena pospolitej gorzałki w latach 1806-1807 to $1 \mathrm{fl}$. $16 \mathrm{gr}^{34}$. W konkurencyjnej gorzelni Arnda von Niessena oferowano 36 różnego rodzaju korzennych wódek gatunkowych, w tym 18 delikatesowych (Feine doppelte Brandweine). Były to dubeltowe „Muscat, Canehl, Alkermis, Cordemom, Crombambuli, Rosasolis, Goldwasser, Nelken, Persico, Ratafia, Neunkraft, Citronen, Annies, Pommeranzen, Kümmel, Melis, Wacholder oraz Magen-Essence oder Aloe-Tropfen" 35 . Firma utrzymała się na rynku do końca stulecia (ryc. 1). Likiery gdańskie znajdowały odbiorców polskich, lecz sporą przeszkodą stały się cła chroniące rynek Królestwa Kongresowego ${ }^{36}$.

W 1816 r. gorzelnie miejskie przepalały na gorzałkę 577 łasztów śrutu zbożowego; w całym powiecie produkcja gorzałki wyniosła $1271500 \mathrm{kwart}^{37}$. W latach trzydziestych i czterdziestych XIX w. działało ponad 30 piwowarów oraz co najmniej 105 gorzelników i wytwórców likierów ${ }^{38}$. Jednak, podobnie jak w przypadku piwa, Gdańsk w coraz większym stopniu stawał się importerem netto zarówno wódek gatunkowych, jak i spirytusu ${ }^{39}$. Równocześnie popularność jopenbier i sławnych likierów gdańskich systematycznie spadała nie tylko w Prusach, ale też w innych krajach niemieckich ${ }^{40}$. Wyjątkiem był tradycyjny importer — Wielka Brytania.

${ }^{28}$ Uebersicht. 1820, s. 23.

${ }^{29}$ Danziger Chronik. 1828, s. 86.

${ }^{30}$ Cornell M. 2016, s. 10.

31 Dickens Ch. 2000, s. 261. W polskich tłumaczeniach błędnie nazywana ,gdańską wódką”, zob.: Dickens K. 1938, s. 247; Dickens K. 1973, s. 324.

32 Allgemeiner Wohnungs-Anzeiger. 1849, s. 295.

33 Wutstrack Ch.F. 1807, s. 396-397 (270-271).

${ }^{34}$ Furtak T. 1935, s. 238, tab. 114; s. 136-137, tab. 24 - ceny gorzałki żytniej w latach 1710-1802.

35 Preis-Courant. (ok. 1808).

36 Wachowiak B. 1981, s. 5-44.

37 Uebersicht. 1820, s. 23.

38 Adress-Buch. 1836-1839, s. 105 — właściciele browarów; s. 106 — właściciele gorzelni; s. 110-112 — destylatorzy wódek gatunkowych; Conversations-Lexicon. 1845-1846, Bd. 7, s. 924.

39 Wachowiak B. 1981, s. 36-37, tab. 6 - statystyka przywozu z lat 1833-1843.

40 Symptomatyczny jest zarówno brak hasła ,jopenbier”, jak i brak wzmianek o browarnictwie gdańskim w wielkiej encyklopedii Conversations-Lexicon. 1845-1846, Bd. 4, Abt. 4, s. 941-946, Bier; Bd. 5, s. 610-644, Brauerei. 
Ryc. 1. Reklama gorzelni „A. von Niessen”, Adreß-Buch. 1884, V Theil, s. 5

Fig. 1. Advertisement for the distillery of A. von Niessen,

Adreß-Buch. 1884, V Theil, p. 5

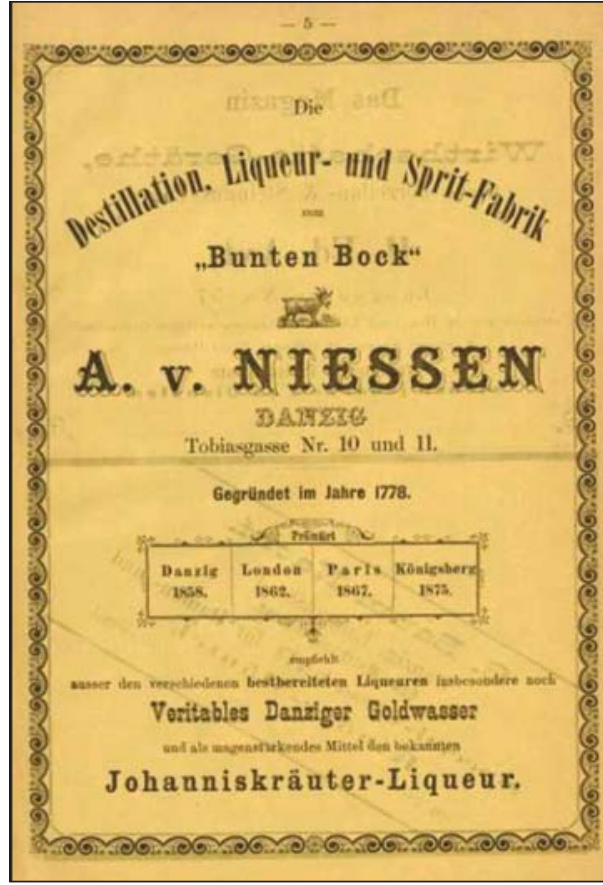

Średnia wywozu jopenbier na tamtejszy rynek w latach 1862-1865 r. wyniosła 24950 achteli (ponad 90 tys. litrów) i była niższa aniżeli w latach 1859-186041. Wartość eksportu oceniano na 86500 talarów (ok. 13000 funtów) ${ }^{42}$. Przeciętna cena beczki (=100 kwart) jopenbier w Gdańsku w 1864 r. wahała się od 18²/3 do 19 talarów, tańsze było piwo w typie koźlaka (Bock- und Salvator-Bier), które kosztowało 10-12 tl., oraz najczęściej już spożywane piwa typu bawarskiego (6-7 tl.). Zwykłe piwa ciemne i jasne były w cenie 4-6 tl., a lekkie piwo stołowe (Halbbier) - od 22/3 do 3 tl. za beczkę ${ }^{43}$.

Zarówno zestawienia statystyczne H. Oelrichsa, jak i roczne raporty opracowywane przez gdańskich kupców w połowie stulecia (w latach 1854-1863), przedstawiają szacunki produkcji jopenbier, nie wzmiankując już w ogóle o produkcji gorzelniczej, co świadczy o braku większego znaczenia tej wytwórczości w ówczesnym bilansie handlowym miasta. Produkcja piwa i wódek pozostała istotną gałęzią działalności gospodarczej, lecz rozproszenie kapitału miało bardzo niekorzystny wpływ na konkurencyjność miejscowych wyrobów. Dodatkowo miejscowym piwowarom i gorzelnikom przyszło się wkrótce zmierzyć z wyzwaniami epoki przemysłowej oraz gustami konsumentów masowych.

Gdańskie produkty były stosunkowo drogie i silnie uzależnione od cen surowca, przede wszystkim jęczmienia. W 1854 r. wyprodukowano ok. 49-50 tys. beczek (Achtel Tonne), jednak cena sprzedaży jednej beczki spadła do $75 \mathrm{sgr}$, co nie pozwalało na pokrycie kosztów wytwarzania $^{44}$. Wpłynęło to na ograniczenie produkcji w latach następnych. W 1856 r. wyprodukowano tylko ok. 15000 beczek (Achtel-Tonne) ${ }^{45}$, przy średnich kosztach uwarzenia jednej

${ }^{41}$ Statistische Mittheilungen. 1867, s. 41.

${ }^{42}$ Cornell M. 2016, s. 10.

${ }^{43}$ Statistische Mittheilungen. 1867, s. 101.

${ }_{44}$ Bericht der Aeltesten. 1854, s. 229.

45 Jahresbericht der Aeltesten. 1856, s. 426. 
beczki jopenbier 102 sgr i cenach zbytu 85-90 sgr. Wyeksportowano 20400 beczek, w magazynach zostało 5000 beczek. Produkcja w 1858 r. wzrosła do 30000 beczek, zaś eksport do 34000 beczek. Spadek cen jęczmienia, przy cenie zbytu w granicach 75-80 sgr za beczkę, pozwalał na uzyskanie umiarkowanego zysku ${ }^{46}$. W 1863 r. produkcja jopenbier wyniosła zaledwie 16500 beczek w większości wywiezionych do Angliii ${ }^{47}$. Inne gatunki piwa produkowanego w Gdańsku dość rzadko trafiały do odbiorców obcych. Wyjątkowo piwo typu bawarskiego (Bairisch Bier) z browaru Ottona Fr. Drewke oferowano w sąsiednim Elblągu, w cenie 3 tl. i 15 gr. za pół beczki ${ }^{48}$.

Producenci gdańscy podejmowali starania o pozyskanie odbiorców na rynkach ogólnoniemieckich. Byli obecni w Berlinie na zorganizowanej latem 1844 r. pierwszej ogólnoniemieckiej wystawie przemysłowej. W berlińskim Arsenale wystawili swoje wyroby browarnicy (Dalmer, Drewke i Mayer) oraz gorzelnicy (Steiff, Keiler i Fischer) ${ }^{49}$. Wyroby gdańskich browarników (piwa typu bawarskiego wystawione przez browar Drewkego oraz porter Mayera i Steiffa) otrzymały wysokie oceny rzeczoznawców. Poza koźlakiem Mayera, który skwaśniał z powodu panujących upałów, reszta napojów zachowała swoje dobre walory smakowe. Tylko jopenbier przywieziony przez Steiffa sprawił pewien kłopot rzeczoznawcom: [...] setzt uns in Verlegenheit. Dies Bier ist der Braunschweiger Mumme ähnliches, überaus extracktreiches, tiefbraunes, süsliches Bier, ohne alle schärfe. Es ist dabei nicht übermäßig geistig, jedennfalls sehr nahrhaft ${ }^{50}$. Gdański browarnik podał, że w 1843 r. wyeksportował za granicę 3110 achteli oraz 166 półachteli tego piwa w cenie 2 za achtel. Za porter i jopenbier wyróżniono wytwórnię Dalmera ${ }^{51}$; nagrody otrzymali też producenci mocniejszych wyrobów spirytusowych: G.A. Fischer, ówczesny właściciel wytwórni „Pod Łososiem” ${ }^{52}$, jak i firma J.S. Kailera, działająca od 1814 r. ${ }^{53}$

Ciężkie piwa jęczmienne w całych Niemczech systematycznie były wypierane przez zyskujące na popularności piwa typu bawarskiego (Märzenbier — piwo marcowe), austriackiego (Lager-Bier) oraz czeskiego (Pils, pilzner), które warzono według dawnych, lecz udoskonalonych technologii produkcji $i^{54}$. Podstawowe znaczenie odgrywało upowszechnienie warzenia w oparciu o fermentację dolną brzęczki piwnej w niższych temperaturach. Piwa w ten sposób warzone były nie tylko bardziej klarowne, lecz również, dzięki dużej ilości dwutlenku węgla, odznaczały się dobrymi właściwościami orzeźwiającymi, co przyczyniało się do ich rosnącej popularności, tworząc podstawy pod współczesną kulturę konsumpcji piwa ${ }^{55}$. Dyskusję o sposobach produkcji prowadzono na łamach specjalistycznych czasopism, m.in. „Allgemeinen bayerischen Hopfen-Zeitung" (od 1861 r.), wydawanego od 1882 r. jako ogólnoniemieckie

46 Jahresbericht der Aeltesten. 1858, s. 623; zob. też: Jahresbericht der Aeltesten. 1859, s. 310.

47 Jahresbericht der Aeltesten. 1863, s. 25; zob. produkcja w latach 1862-1865, Statistische Mittheilungen. 1867, s. 41.

${ }^{48}$ Elbinger Zeitung. 1842, nr 5, 19 I 1842.

49 Neukrantz A.F. 1845, s. 70-71, m.in. próbki piwa gdańskiego.

${ }_{50}$ Amtlicher Bericht. 1845, Bd. 4, s. 71. O rzekomo ,wstrętnym słodkawym smaku” tych piw (widerlichsüßen Geschmack) pisano w poradniku: Müller P. 1854, s. 2.

${ }^{51}$ Amtlicher Bericht. 1845, Bd. 4, s. 71.

52 Skrytykowano wyroby wytwórni „Pod Łososiem”, m.in. słabo był wyczuwalny smak korzenny, zbyt mało cukru oraz wysoką cenę (od 1 do 1 2/3 talara za 3/5 kwarty): [...] dürfte doch die Mischung der Gewürze hier weniger zusagen; sie sind nicht einfach genug. Die Liqueure sind hinreichend stark, dürften indeß noch etwas mehr Zucker vertragen, was jedoch nur von ein feinsten gilt; auch namentlich für diese eine größere Dicksüssigkeit zu wünschen sein, die namentlich für das sonst berühmte Danziger Goldwasser nothwendig ist, wenn die drin vertheilten Goldflitter nicht augenblicklich wieder zu Boden fallen sollen, zob.: Amtlicher Bericht.1845, Bd. 4, C, s. 78. Uznanie uzyskały wytwory dużej firmy „Härtel u. Co.” z Elbląga.

${ }_{53}$ Uebersicht der Auszeichnungen. 1844, s. 24, nr 531, 533; s. 34, nr 299-300.

54 Teich M. 2000, s. 58-92.

55 Tappe H. 1994. 
Ryc. 2. Reklama browaru i gorzelni „G.F.A. Steiff”, Adreß-Buch. 1884, III Theil, po s. 70

Fig. 2. Advertisement for the brewery and distillery G.F.A. Steiff, Adreß-Buch. 1884, III Theil, after p. 70

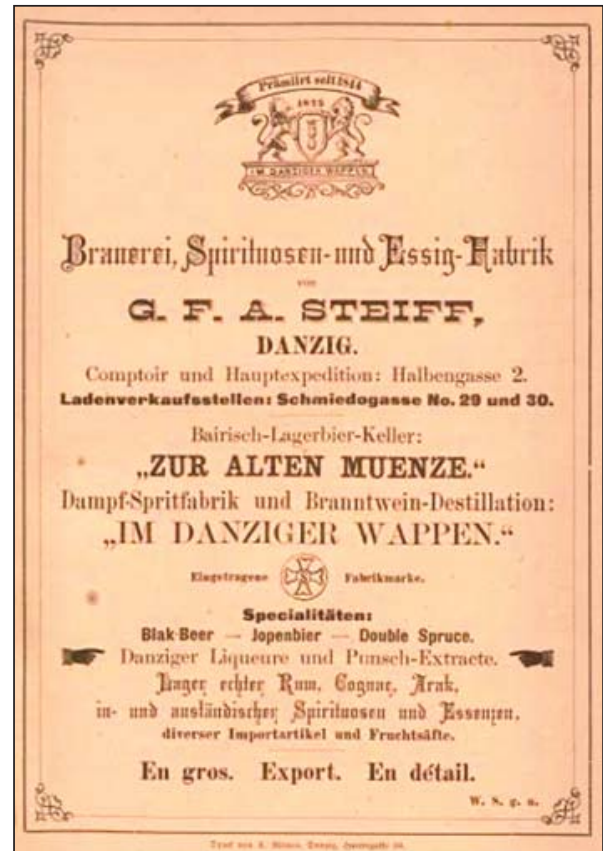

„Zeitschrift für das gesamte Brauwesen”. Zmiany technologiczne, wprowadzane np. dzięki nowo wyhodowanym szczepom drożdży (np. Saccharomyces carlsbergensis), dodatkowo przyczyniły się do wypierania tradycyjnych sposobów produkcji opartych zwyczajowo na fermentacji w wyższych temperaturach (górna fermentacja).

Boleśnie przekonał się o tym browar Steiffa, który wystawił swoje tradycyjne produkty na wielkiej wystawie przemysłowej w Monachium w 1854 r. Jopenbier tak dalece już odbiegał od powszechnie znanych piw, że komisja rzeczoznawców uchyliła się od oceny samego wyrobu, nie miała bowiem pewności, czy w ogóle ten napój należy traktować jako rodzaj piwa. Ograniczono się do odnotowaniem cech fizycznych trunku oraz informacji, że produkt jest wysyłany do Anglii celem poprawienia jakości tamtejszego portera ${ }^{56}$. Poza browarami Steiffa (ryc. 2) i Rodenackera, ostatnim liczącym się producentem i eksporterem tego piwa pozostawał jeszcze browar Roberta Fischera w podgdańskim Nowym Porcie ${ }^{57}$, który jeszcze w 1886 r. utrzymywał swoich agentów w Glasgow. Jednak rynek konsumentów nieubłaganie się kurczył, albowiem również w samej Anglii odchodzono od tradycyjnych piw ${ }^{58}$, mimo że jeszcze w 1877 r. sprowadzono na tamtejszy rynek 389449 litrów (28 100 baryłek) jopenbier ${ }^{59}$.

Ze zmian przyzwyczajeń konsumpcyjnych zdawano sobie sprawę również w Gdańsku, czego dowodem był sukces założonej w 1871 r. spółki akcyjnej „Danziger Aktien-Bierbrauerei” (dalej cyt.: DAB). Wzniesiona we Wrzeszczu-Kuźniczkach wytwórnia, która dysponowała pierwszym w Gdańsku numerem telefonicznym (nr 1), specjalnym ujęciem wody oraz własną bocznicą kolejową, uruchomiła produkcję w połowie 1873 r. ${ }^{60}$ DAB koncentrował się na prze-

${ }^{56}$ Bericht der Beurtheilungs-Commission. 1855, s. 15.

57 Trzech wytwórców tego piwa wyszczególniono w 1884 r., Adreßbuch. 1884, s. 12, IV Theil.

${ }^{58}$ Wilson R.G. 1998, s. 78-89.

${ }^{59}$ Cornell M. 2016, s. 10.

${ }^{60}$ Danziger Actien-Bier-Brauerei. 1897. 


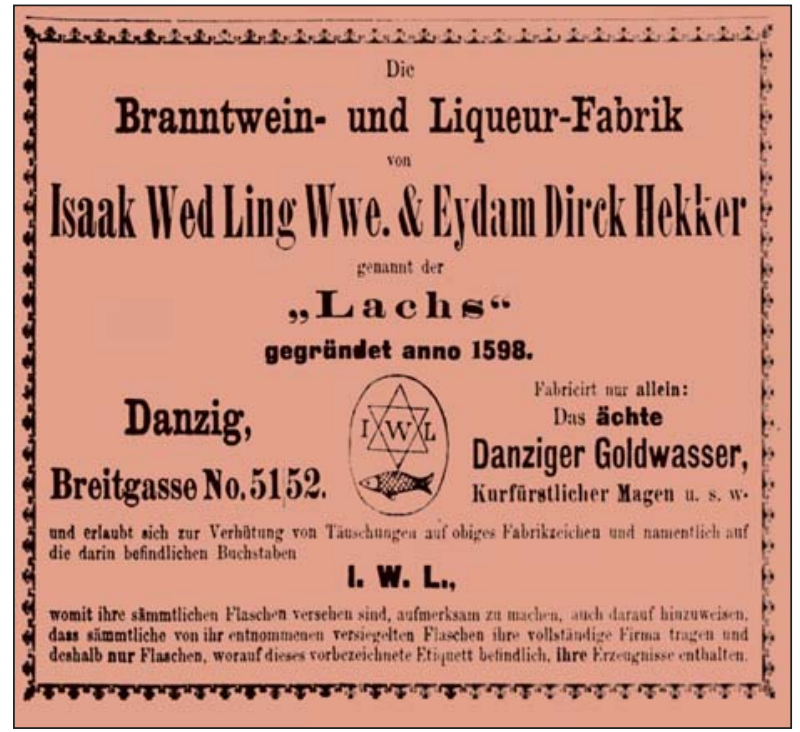

\section{Ryc. 3. Reklama gdańskiej gorzelni „Pod Łososiem”, Adreß-Buch. 1888, V Theil, s. 38}

Fig. 3. Advertisement for the Gdańsk distillery "Pod Łososiem", Adreß-Buch. 1888, V Theil, p. 38

mysłowej produkcji lżejszych piw dolnej fermentacji ${ }^{61}$, co przyczyniło się do wyparcia z rynku słabszej konkurencji. Pod koniec XIX stulecia (w 1895 r.) w mieście działało jeszcze 12 browarów, dysponujących 15 maszynami parowymi i zatrudniających 301 osób $^{62}$. Największe znaczenie miała DAB (75 pracowników, rok wcześniej - 50). W 1897 r. zatrudnienie wzrosło w firmie do 89, zaś do 166 osób w roku 1908. Akcjonariusze firmy w roku budżetowym 1912/ 1913 otrzymali 12\% dywidendy od zysku netto w wysokości 380239 marek $^{63}$.

Pozostałe browary były znacznie mniejsze. Trzy firmy należące do rodziny Fischerów w 1908 r. zatrudniały odpowiednio: Richard Fischer - 36 pracowników, u następców A. Fischera juniora - 20 osób, zaś w browarze Paula Fischera - 36 osób. Do tej kategorii wielkości należał browar następców Drewkego („Brauerei J. von Puttkamer vorm. O.F. Drewke”), zatrudniający 33 osoby oraz „Alte Danziger Brauerei E. Rodenacker” — 26 osób; najmniejsza była wytwórnia L.O. Kämmerera (13 pracowników ${ }^{64}$. Łączna produkcja gdańskich browarów w 1905 r. wyniosła 202000 hl ${ }^{65}$. Ostatecznie na rynku w przededniu wybuchu wojny utrzymało się 9 browarów. Rozpoczęcie działań wojennych w 1914 r. w sposób nagły zatrzymało tradycyjny eksport do Anglii, co wraz z reglamentacją dostaw i konsumpcji zbóż na niemieckim rynku wewnętrznym zasadniczo położyło kres długim dziejom jopenbier w Gdańsku.

O ile doszło do koncentracji oraz uprzemysłowienia browarnictwa gdańskiego, o tyle uderzająco anachroniczny charakter zachowało 18 działających pod koniec XIX w. wytwórni wódek. Poza fabryką Steiffa z 36 pracownikami, zatrudniały one w 1893 r. łącznie 57 osób, a w 1897 - 77, czyli po kilka na zakład. Niekiedy były to firmy jednoosobowe („Böhnke”, „Muskalla”, „Bohmann” ${ }^{66}$. Dość powiedzieć, że w firmie „Pod Łososiem”, należącej w tym czasie do Emila Unruha, pracowało w latach 1897-1898 zaledwie 6 osób (ryc. 3). Opubliko-

${ }^{61}$ Pfannenschmidt E. 1880, s. 216.

${ }^{62}$ Bericht. 1894/1895, s. 155, zestawienie sumaryczne. W raporcie z poprzedniego roku zatrudnienie w browarach wynosiło 270 osób, Bericht des Magistrats. 1893/1894, s. 160-161.

${ }^{63}$ Ostdeutsche Industrieller. 1913, nr 13, 15 XII 1913.

64 John W. 1908, s. 381-384.

${ }_{65}$ Włodarczyk E. 1998, s. 327-328.

${ }_{66}$ Bericht. 1893/1894, s. 160-161; Bericht. 1897/1898, s. 191-192. 
Ryc. 4. Reklama likieru Drei Grazien z gorzelni ,J.S. Keiler. Nachfolger”, ok. 1900 r., BG PAN, sygn. Sz 4/5-101

Fig. 4. Advertisement for "Drei Grazien" liqueur from the J.S. Keiler distillery, Nachfolger,

ca. 1900, BG PAN, Inv. No Sz 4/5-101

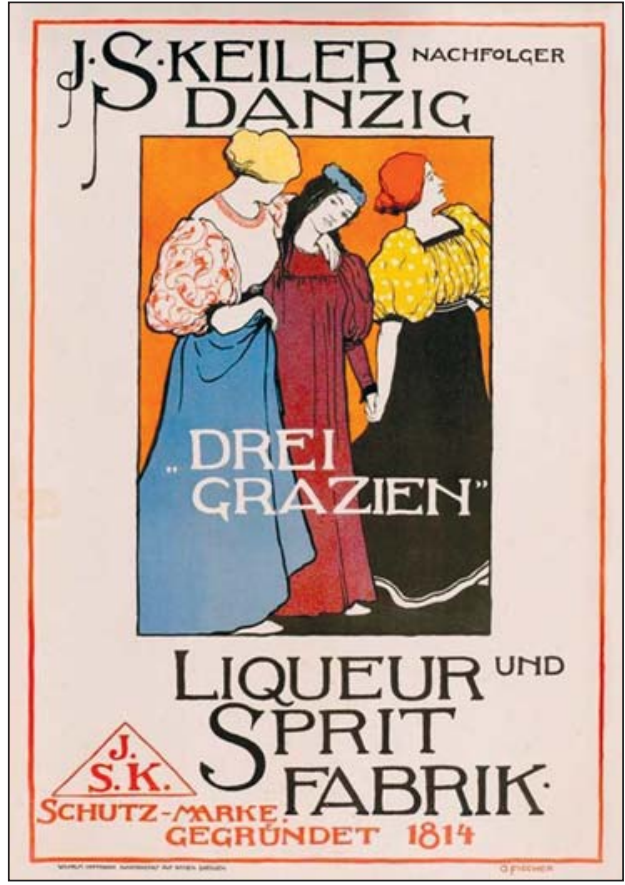

wana w 1898 r. jubileuszowa broszura przypomniała o liczącej 300 lat historii zacnej firmy, co samo w sobie miało spory potencjał symboliczny i sentymentalny, lecz tylko niewielki gospodarczy ${ }^{67}$. Na rynku poza przedsiębiorstwem G.F.A. Steiffa liczyły się jeszcze wytwórnie: „A.H. Pretzell”, „Gustav Springer Nachfolger”, ,J.S. Keiler Nachfolger” oraz „L. Matzka Nachfolger”. Sprzedawały produkty przede wszystkim na rynku lokalnym, eksportując tylko w ograniczonej skali. Należy wspomnieć jednak, że na wielkiej wystawie przemysłowej w Wiedniu w 1873 r. zaprezentowano wyroby „Pod Łososiem” (Goldwasser i Kurfürstlicher Magen) oraz firmy „J.S. Keiler Nachfolger” (Goldwasser, Doppelt-Cordial) ${ }^{68}$. Według informacji uzyskanych od właścicieli, ta ostatnio wyprodukowała 2740001 likierów i wódek, uzyskując ze sprzedaży 80 tysięcy talarów (zob. ryc. 4). Wytwórnia „J. S. Keiler” reklamowała swoje wyroby m.in. na wystawie światowej w Filadelfii w USA (w 1874 r.), jednak bez większych efektów. Na rynku lokalnym konkurencja z Prus Zachodnich oferowała podobne produkty za niższą cenę, np. istniejąca od 1776 r. wytwórnia Heinricha Stobbe z żuławskiego Nowego Dworu (sławna jałowcówka Machandel) lub toruńscy producenci likieru Thorner Lebenstropfen, nie wspominając o licznych gorzelniach wiejskich wytwarzających tanią wódkę z ziemniaków.

Nawet stare i powszechnie uznane marki gdańskich wyrobów nie były w stanie obronić swej dawnej pozycji w walce o zmieniające się gusty konsumentów epoki przemysłowej. Niska koncentracja kapitału oraz ogólne zacofanie przemysłowe Prus Zachodnich i Wschodnich na tle reszty państwa pruskiego, przy równoczesnym trwaniu przy rzemieślniczej organizacji pracy, skutkowały niewielką skalą produkcji przy wysokich cenach zbytu. Brak środków ograniczał wydatki na reklamę, możliwość okresowych obniżek cen oraz ekspansji na rynki dużych miast niemieckich. Uderzająca jest mała ilość informacji o miejscowych piwach i wódkach

67 Festschrift. 1898.

${ }^{68}$ Wiener Weltausstellung. 1873, s. 174. 
w gazetach gdańskich oraz w księgach adresowych ${ }^{69}$, szczególnie na tle ogłoszeń firm zachwalających wyroby dostarczane z innych regionów Niemiec, a także z importu zagranicznego. Również spadek kosztów transportu kolejowego nie wpływał korzystnie na ochronę rynku lokalnego przed obcą konkurencją. Problemy gdańskich producentów piwa i wódek gatunkowych odzwierciedlały ogólną słabość gdańskiego ośrodka przemysłowego na mapie gospodarczej Prus oraz Cesarstwa ${ }^{70}$. Podobnie jak innym branżom przemysłowym, miejscowym browarom i gorzelniom nie udało się w XIX w. i na początku XX stulecia wprowadzić na rynek żadnego wyrobu, który stałby się marką trwale kojarzoną z miastem. Pozostała wiara w siłę legendy ${ }^{71}$.

Adres Autora:

prof. dr hab. Edmund Kizik

Instytut Historii

Uniwersytet Gdański

ul. Wita Stwosza 55

80-308 Gdańsk

edmund.kizik@ug.edu.pl_

https://orcid.org/0000 000258772025

\section{BIBLIOGRAFIA}

\section{Źródla archiwalne}

Reklama likieru. b.r. (ok. 1900). Reklama likieru „Drei Grazien” z gorzelni „J.S. Keiler. Nachfolger”, BG PAN [Biblioteka Gdańska PAN], sygn. Sz 4/5-101.

Wutstrack Christian F. 1807. Historisch-topographisch-statistische Nachrichten von der KöniglichWestpreussischen See- und Handels-Stadt Danzig..., Danzig, APG [Archiwum Państwowe w Gdańsku], sygn. 300, R/ L1 96.

\section{Źródła i opracowania opublikowane}

Adreß-Buch. 1817. Adreß-Buch für das Königliche Danziger Regierungs-Departement mit besonderer Berücksichtigung der Stadt Danzig und ihres Polizei-Bezirks, Danzig.

Adress-Buch. 1836-1839. Adress-Buch der Stadt Danzig und der dazu gehörigen Vorstädte, Danzig.

Adreß-Buch. 1884. Adreß-Buch für die Provinzial-Hauptstadt Danzig und deren Vorstädte für 1884, Danzig.

Adreß-Buch. 1888. Adreß-Buch für die Provinzial-Hauptstadt Danzig und deren Vorstädte für 1888 , Danzig.

Allgemeiner Wohnungs-Anzeiger. 1849. Allgemeiner Wohnungs-Anzeiger für Danzig und dessen Vorstädte, auf das Jahr 1849, Danzig.

Amtlicher Bericht. 1845. Amtlicher Bericht über die allgemeine Deutsche Gewerbe-Ausstellung zu Berlin im Jahre 1844, Bd. 3-4, Berlin.

Barylewska-Szymańska Ewa, Maciakowska Zofia. 2016. Miasto i ludzie u progu nowoczesności. Socjotopografia Gdańska w pierwszej połowie XIX wieku, Studia i materiały do dziejów domu gdańskiego, cz. 4, red. E. Kizik, Gdańsk-Warszawa.

${ }^{69} \mathrm{Z}$ reguły są to niewielkie anonse, np. reklama browaru „H.W. Mayer” (zob.: Danziger Zeitung. 1902, nr 527, 11 IX 1902) lub reklamy wyrobów browarów krajowych i zagranicznych w składzie Roberta Krügera (zob.: Neuer Wohnungs-Anzeiger. 1872, wkładka reklamowa).

${ }^{70}$ Problemom z rozwojem przemysłu gdańskiego w XIX w. poświęciłem osobne opracowanie, Kizik E. (w druku).

71 Produkcji ,złotej wódki” podjętej po wojnie m.in. w zakładach „Polmos” w Pruszczu Gdańskim zaprzestano w 2009 r. Tradycję kontynuuje następca prawny gdańskiego „Pod Łososiem” w dolnosaksońskim NörtenHardenberg („Hardenberg-Wilthen AG”), zob.: Müller N., Borzestowski W. 2010, s. 29-39. Przemysłową produkcję piwa w Gdańsku zakończono w 2001 r. wraz z likwidacją zakładu na terenie dawnego browaru DAB we Wrzeszczu-Kuźniczkach, zob.: Browar Gdański. 2021. 
Bericht der Aeltesten. 1854. Bericht der Aeltesten der Kaufmannschaft über den Handel und die Schieffahrt zu Danzig im Jahre 1854, „Handels-Archiv“, 1855, Bd. 1, s. 221-232.

Bericht der Beurtheilungs-Commission. 1855. Bericht der Beurtheilungs-Commission bei der Allgemeinen Deutschen Industrie-Ausstellung zu München im Jahr 1854, München.

Bericht des Magistrats der Stadt Danzig. 1893/1894, 1894/1895, 1897/1898. „Bericht des Magistrats der Stadt Danzig", Danzig.

Biernat Czesław. 1962. Statystyka obrotu towarowego Gdańska w latach 1651-1815, Warszawa.

Biernat Czesław. 1993. Handel, żegluga, wytwórczość, [w:] Historia Gdańska, t. 3, cz. 2: 1793-1815, red. E. Cieślak, Gdańsk.

Blänckenburg Christine von. 2000. Hanse und ihr Bier. Brauwesen und Bierhandel im hansischen Verkehrsgebiet, Quellen und Darstellungen zur hansischen Geschichte, N.F. 51, Köln.

Browar Gdański. 2021. Browar Gdański, http://www.browargdanski.pl/historia (dostęp 01.03. 2021).

Dabkiewicz J. 1838. Spiżarnia wiejska obywatelska, Wilno.

Danziger Actien-Bier-Brauerei. 1897. Danziger Actien-Bier-Brauerei. Geschäftsbericht über das Geschätsjahr 1896/97, Danzig.

Danziger Chronik. 1828. Danziger Chronik der Jahre 1827 und 28, red. G. Löschin, Danzig.

Conversations-Lexicon 1845-1846. Das große Conversations-Lexicon für die gebildeten Stände, red. J. Meyer, Bd. 4-5, 7, Hildburghausen.

Cornell Martyn. 2016. A short History of Spruce Beer in Britain, „Journal of the Brewery History Society", vol. 165, s. 2-14.

Dickens Charles. 2000. The Pickwick Papers, b.m.

Dickens Karol. 1938. Klub Pickwicka, t. 2, Warszawa.

Dickens Karol. 1973. Klub Pickwicka, t. 1, tłum. W. Górski, Warszawa.

Dover Telegraph. 1834. „Dover Telegraph and Cinque Ports General Advertiser”.

Elbinger Zeitung. 1842. „Elbinger Zeitung”.

Festschrift. 1898. Festschrift über das 300jährige Bestehen der Liqueur-Farbrik „, Der Lachs,, Firma Isaak Wed-Ling Wwe u. Eidam Dirck Hekker zu Danzig..., Nürnberg.

Furtak Tadeusz. 1935. Ceny w Gdańsku w latach 1701-1815, Lwów.

Gedanopedia. 2021. Gedanopedia, https://www.gedanopedia.pl/gdansk/?title=PIWO_ GDA\%C5\%83SKIE (dostęp 01.02.2021).

Gerber. 1797. Statistische Nachrichten von Danzig aus der zweiten Hälfte des Jahres 1796, „Preußisches Archiv”, April, s. 282-290.

Jahresbericht der Aeltesten. 1855. Jahresbericht der Aeltesten der Kaufmannschaft zu Danzig für das Jahr 1855, „Preußisches Handels-Archiv”, 1856, Bd. 1, s. 264-274.

Jahresbericht der Aeltesten. 1856. Jahresbericht der Aeltesten der Kaufmannschaft zu Danzig für das Jahr 1856, „Preußisches Handels-Archiv”, 1857, Bd. 1, s. 422-428, 446-450.

Jahresbericht der Aeltesten. 1858. Jahresbericht der Aeltesten der Kaufmannschaft zu Danzig für 1858, „Preußisches Handels-Archiv”, 1859, Bd. 1, s. 605-611, 620-628.

Jahresbericht der Aeltesten. 1859. Jahresbericht der Aeltesten der Kaufmannschaft zu Danzig für 1859, „Preußisches Handels-Archiv”, 1860, Bd. 1, s. 278-281, 304-311.

Jahresbericht der Aeltesten. 1861. Jahresbericht der Aeltesten der Kaufmannschaft zu Danzig für 1861, „Preußisches Handels-Archiv”, 1862 (Beilage), s. 7-25.

Jahresbericht der Aeltesten. 1863. Jahresbericht der Aeltesten der Kaufmannschaft zu Danzig für 1863, „Preußisches Handels-Archiv”, 1864 (Beilage), s. 17-34.

John Wilhelm. 1908. Danzigs Industrie, [w:] Danzig und seine Bauten, Danzig, s. 381-384.

Kitowicz Jędrzej. 1985. Opis obyczajów za panowania Augusta III, Warszawa.

Kizik Edmund. 1994. Mennonici w Gdańsku, Elblagu i na Żuławach Wiślanych w drugiej połowie XVII $i$ w XVIII w., Gdańsk.

Kizik Edmund. 2019. Wspótczesne badania polskie z zakresu historii kultury materialnej epoki nowożytnej, „Czasy Nowożytne”, t. 32, s. 12-52.

Kizik Edmund (w druku). Gdańsk na wystawach przemysłowych w ,,dtugim XIX wieku” (do 1914 r.).

Kleist von Heinrich. 1811. Der zerbrochne Krug, ein Lustspiel, Berlin.

Klonder Andrzej. 1983. Browarnictwo w Prusach Królewskich (2 połowa XVI-XVII w.), Wrocław. 
Klonder Andrzej. 1989. Napoje fermentacyjne w Prusach Królewskich w XVI-XVII wieku (produkcja — import - konsumpcja), Studia i Materiały z Historii Kultury Materialnej, t. LX, red. Z. Kamieńska, Wrocław.

Lessing Gotthold Ephraim. 1767. Minna von Barnhelm oder das Soldatenglück. Ein Lustspiel in fünf Aufzügen, Berlin.

Literary Panorama. 1808. „The Literary Panorama”, vol. 3, March.

Löschin Gotthilf. 1837. Die Danziger Brauerzunft, [w:] Beiträge zur Geschichte Danzigs und seiner Umgebungen, H. 3, wyd. G. Gotthilf, Danzig, s. 3-22.

Ludwig Karl-Heinz. 1961. Zur Besiedlung des Weichseldeltas durch die Mennoniten. Die Siedlungen der Mennoniten im Territorium der Stadt Elbing und die Ökonomie Marienburg bis zur Übernahme der Gebiete durch die Preußen 1772, Marburg/Lahn.

Marcinkiewicz Alicja. 2018. Dzieje Królewskiego Zespolonego Miasta Chetm w latach 1772-1813, [w:] Historie gdańskich dzielnic, t. 1: Chetm, red. J. Dargacz, K. Kurkowska, P. Pluchowski, Gdańsk, s. 226-251.

Mickiewicz Adam. 1834. Pan Tadeusz czyli ostatni zajazd na Litwie, Paryż.

Müller Natalia, Borzestowski Waldemar. 2010. Goldwasser, „30 dni”, nr 2, s. 29-39.

Müller P. 1854. Handbuch für Bierbrauer: eine wissenschaftlich-praktische Anleitung zum Bierbrauen, Braunschweig.

Neuer Wohnungs-Anzeiger. 1872. Neuer Wohnungs-Anzeiger nebst Allgem[eine] Geschäfts-Anzeiger für Danzig und den Vorstädten..., Danzig.

Neukrantz A.F. 1845. Ausführlicher Bericht über die große, allgemeine deutsche Gewerbe-Ausstellung in Berlin im Jahre 1844, Berlin.

Neu-revidirte Willkühr. 1783. Neu-revidirte Willkühr der Stadt Danzig aus Schluß sämtlicher Ordnung publicirt Anno 1761, Danzig.

Ostdeutsche Industrieller. 1913. „Ostdeutsche Industrieller”.

Pfannenschmidt Eduard. 1880. Ueber die Industrie Danzigs und seiner nächsten Umgebung, [w:] Danzig in naturwissenschaftlicher und medizinischer Beziehung, Danzig.

Preis-Courant. (ok. 1808). Preis-Courant der Danziger Brandtweine und Liquere, welche fabricirt und zu bekommen sind bei Arend von Niessen in Danzig, in der Tobiasgasse, bey Zeichen bunte Bock, Danzig (unikat: Biblioteka Gdańska PAN, sygn. Od $116494^{\circ}$ ).

Public Ledger. 1807. „The Public Ledger and Commercial and General Advertiser”.

Romanow Andrzej. 1983. Materiały do dziejów spławu na Sanie i Wiśle. „Fryor gdański” Pawła Boenego, kasztelana warszawskiego, „Rocznik Gdańsk”, t. 43, z. 1, s. 167-212.

Rostworowski Stefan Marian. 1933-1934. Co szlachcic polski w XVIII wieku kupowat w Gdańsku, „Rocznik Gdański”, t. 7-8, s. 348-384.

Statistische Mittheilungen. 1867. Statistische Mittheilungen über den Regierungsbezirk Danzig, oprac. H. Oelrichs, Danzig.

Syrennius Simon. 1613. Zielnik, herbarzem z ięzyka łacinskiego zowia, Cracovia.

Tappe Heinrich. 1994. Auf dem Weg zur modernen Alkoholkultur. Alkoholproduktion, Trinkverhalten und Temperenzbewegung in Deutschland vom frühen 19. Jahrhundert bis zum Ersten Weltkrieg, Stuttgart.

Tarnowski S. 1882. Z Prus Królewskich, Kraków (nadbitka z: „Przegląd Polski”, t. 63, 1882, z. 7, s. 23-59; z. 8, s. 181-236).

Teich M. Mikuláš. 2000. Bier, Wissenschaft und Wirtschaft in Deutschland 1800-1914. Ein Beitrag zur deutschen Industrialisierungsgeschichte, Wien.

Trzoska Jerzy. 1984. Z dziejów gorzelnictwa gdańskiego $w$ drugiej połowie XVII $i$ w XVIII wieku, „Rocznik Gdański”, t. 44, z. 1, s. 145-187.

Uebersicht. 1820. Uebersicht der Bestandtheile und Verzeichniß alle Ortschaften des Danziger Regierungs-Bezirkes, Danzig.

Uebersicht der Auszeichnungen. 1844. Uebersicht der Auszeichnungen welche in Folge der GewerbeAusstellung zu Berlin im Jahre 1844 ertheilt werden sind [przedruk listy za „Allgemeine Preußische Zeitung", nr 52, 21 II 1845], [w:] Amtlicher Bericht über die allgemeine Deutsche Gewerbe-Ausstellung zu Berlin im Jahre 1844, Bd. IV, Berlin 1845, s. 1-36 (osobna paginacja wewnątrz tomu). 
Wachowiak Bogdan. 1981. Problemy handlu gdańskiego w pierwszej połowie XIX wieku, „Rocznik Gdański”, t. 42, z. 2, s. 5-44.

Wedekind Christoph Friedrich. 1746. Der Krambambulist. Ein Lob-Gedicht über die gebrannten Wasser im Lach $\beta$ zu Dantzig, wyd. 2, Halle.

Wiadomość. 1769. Wiadomość ciekawa, każdemu wielce pożyteczna o skutkach y mocy zbóż wszelkich..., Łowicz.

Wiener Weltausstellung 1873. Wiener Weltausstellung. Amtlicher Katalog der Ausstellung des Deutschen Reiches, Berlin.

Wilson Richard George. 1998. The Changing Taste for Beer in Victorian Britain, [w:] The Dynamics of the international brewing industry since 1800, red. R.G. Wilson, T.R. Gouvrish, New York, s. $78-89$.

Włodarczyk Edward. 1998. Rozwój gdańskiego przemysłu i rzemiosła, [w]: Historia Gdańska, t. IV, cz. 1: 1815-1920, red. E. Cieślak, Sopot, s. 334-340.

\section{Goldwasser and Jopenbier: Vodka and beer production in Gdańsk in the "long" 19th century (until 1914)}

The products of Gdańsk brewers and distillers, especially heavy barley beer (Jopenbier) and spicy liqueurs, enjoyed great fame in Poland and throughout Central and Eastern Europe in the 17th-18th centuries. The taste and appearance of Gdańsk vodka (Goldwasser) was praised by German poets, and was even mentioned in the Polish national epic Pan Tadeusz (1834).

This paper discusses the situation of the Gdańsk distilling and brewing craft from the end of the 18th century until the outbreak of the First World War. Based on trade statistics, the author shows the changing structure of the manufacturers, the production volume and prices, exports, and the reaction to changing consumer tastes in the industrial era.

In 1817, 36 breweries operated in Gdańsk and its suburbs, as well as 18 distilleries producing spirit and as many as 89 spicy vodkas. In the 19th century, the largest (and only) customer for Gdańsk's heavy beer (Jopenbier) was England. Jopenbier, referred to as "double brown stout," "dantzig spruce," or "dantzic black beer," was usually used as a flavour enhancer of porter or light beers with a short shelf life. England remained the only significant market for Jopenbier until the outbreak of the First World War in 1914. In Germany itself, beers like Jopenbier were pushed out of the market as early as the middle of the 19th century by Bavarian and Czech beers produced according to new technologies. Changing tastes influenced the process of concentration and industrialisation in Gdańsk breweries, the majority of which switched to the production of light beers, while most of the 18 Gdańsk distilleries operating at the turn of the 19th and 20th centuries remained family-run workshops of little economic importance. Gdańsk distillers partly carried on using the power of the reputation of the local alcohol production, but the beginning of the 20th c. they were no longer able to maintain old distribution markets and did not introduce any products permanently associated with the city on the Motława River.

Translated by Karolina Płoska

Proofread by Rebecca Gorzynska 